ROCZNIKI HUMANISTYCZNE

Tom LXVI, zeszyt $11-2018$

ZESZYT SPECJALNY/SPECIAL ISSUE

DOI: http://dx.doi.org/10.18290/rh.2018.66.11s-1

BARBARA KLONOWSKA

ZOFIA KOLBUSZEWSKA

GRZEGORZ MAZIARCZYK

\title{
BRAVE NEW HUMAN IN (TRANS/POST)HUMANIST UTOPIAS: AN INTRODUCTION
}

The rapid changes observable in the modern world raise the question whether we can assume that we are on the way towards a new stage in the development of humanity, when transcending numerous biological constraints will make the future human being so different from what we are now that it is fitting to call him/her a posthuman. However, the question what a "brave new human" should be like has actually been asked much earlier - the essence of (e)utopia lies in the vision of the individual and the society that are improved in relation to the world in which the author and his/her readers live. The essays collected in this special issue analyse selected utopias and dystopias from the $16^{\text {th }}$ to the $21^{\text {st }}$ centuries in order to trace the evolution of a traditional model of a human towards a psychologically and/or (bio)technologically enhanced individual triggered by the rise of humanism and the developments in exact and natural sciences, (bio)technology and media, changes that have led to the redefinition of the concept of human nature and its boundaries.

Barbara Klonowska, PhD, DLitt._-John Paul II Catholic University of Lublin, Faculty of Humanities, Institute of English Studies, Department of English Literature and Culture; address for correspondence: Al. Racławickie 14, 20-950 Lublin; e-mail: maple@kul.pl

Prof. ZofiA KolbuSZEWSKA - University of Wrocław, Faculty of Letters, Institute of English Studies, Department of American Literature and Culture; address for correspondence: ul. Kuźnicza 22, 50-138 Wrocław; zofia.kolbuszewska@uwr.edu.pl

Prof. GRZEGORZ MAZIARCZYK - John Paul II Catholic University of Lublin, Faculty of Humanities, Institute of English Studies, Department of American Literature and Culture; address for correspondence: Al. Racławickie 14, 20-950 Lublin; e-mail: crimson@kul.pl 
The posthuman constitutes the key category of transhumanism and posthumanism - two loosely defined movements that explore multiple ramifications of this transformation. The Transhumanist FAQ defines transhumanism as

The intellectual and cultural movement that affirms the possibility and desirability of fundamentally improving the human condition through applied reason, especially by developing and making widely available technologies to eliminate aging and to greatly enhance human intellectual, physical, and psychological capacities.

As noted by David Roden, this school of thought is characterised by a conspicuous ethical dimension: it assumes that the transformation of human being through (bio)technological modifications is a desirable stage in the further development of mankind (9). The Transhumanist Declaration, first published in 1998, asserts the right of human beings to morphological freedom, i.e. the right to fashion oneself via (bio)technological modifications, and thus firmly situates transhumanism in the tradition of secular humanism with its vision of human as a being capable of self-fashioning, most famously expressed in Giovanni Pico della Mirandola's "Oration on the Dignity of Man":

We have set thee at the world's center that thou mayest from thence more easily observe whatever is in the world. We have made thee neither of heaven nor of earth, neither mortal nor immortal, so that with freedom of choice and with honor, as though the maker and molder of thyself, thou mayest fashion thyself in whatever shape thou shalt prefer. (225)

Posthuman is precisely the term that transhumanism employs to designate the self-fashioned "brave new human" of the future. In "The Philosophy of Transhumanism" Max More asserts that "by thoughtfully, carefully, and yet boldly applying technology to ourselves, we can become something no longer accurately described as human-we can become posthuman" (More 4) and ascribes to this future being enhanced physical, cognitive and emotional capabilities, just as Nick Bostrom does in his seminal essay "Why I Want to Be Posthuman When I Grow Up." The infinite potential of posthuman is presented in an even more celebratory manner in Bostrom's "Letter from Utopia," which takes a literary rather than philosophical form of a message from a posthuman being to mankind. As the title indicates, the dramatised sender of the letter explicitly calls the lives he/she and his/her fellow posthumans lead Utopia and in a highly metaphorical passage highlights boundless delights of the posthuman condition: 
... what you had in your best moment is not close to what I have nowa beckoning scintilla at most. If the distance between base and apex for you is eight kilometres, then to reach my dwellings requires a million light-year ascent. The altitude is outside moon and planets and all the stars your eyes can see. Beyond dreams. Beyond imagination.

My consciousness is wide and deep, my life long. I have read all your authorsand much more. I have experienced life in many forms and from many angles: jungle and desert, gutter and palace, heath and suburban creek and city back alley. I have sailed the high seas of cultures, and swum, and dived. (Bostrom 3)

Well aware of negative connotations the actual past attempts to create perfect society may evoke, Bostrom makes his posthuman speaker insist that he "can pass [us] no blueprint for Utopia, no timetable, no roadmap. All [he] can give [us] is [his] assurance that there is something here, the potential for a better life" (Bostrom 7) and thus urge us to embark on the journey towards the state he/she embodies.

This insistence on vast improvement or even perfection, as the passage quoted above seems to suggest, of both individual life and social organisation that the posthuman transformation will bring about throws into sharp relief the utopian underpinnings of tranhumanism. As Michael Hauskeller points out, "transhumanist visions of our post-human future evoke not only mythical places such as the Land of Cockaigne, the Isles of the Blessed, or the Golden Age, in which men lived like Gods. They also echo the promises of alchemy and later of modern science to secure wealth and happiness for all human beings" (12). And yet, despite Bostrom's overt employment of the term, More insists that "transhumanists seek not utopia, but perpetual progressa never-ending movement toward the ever-distant goal of extropia" (14), the latter term being his conceptual alternative to the former. ${ }^{1}$ Somewhat vaguely defined as "the extent of a living or organizational system's intelligence, functional order, vitality, and capacity and drive for improvement" (More 4), extropia highlights the dynamic nature of endless transhumanist advancement, which More contrasts with the utopian stasis of perfection. This discrepancy between these two leading transhumanists' approaches to utopia can be attributed to fundamentally different conceptions of transhumanist teleology. Not only does Bostrom's posthuman sender set the goal for mankind- "Like Odysseus you must journey, and never cease journeying, until you arrive upon this shore" (Bostrom 7) - but also his/her/its words strongly suggest

\footnotetext{
${ }^{1}$ Even though the transhumanist reader More co-edited with Natasha Vita-More contains Bostrom's "Why I Want to Be Posthuman When I Grow Up," which would suggest that he must know his "Letter from Utopia," he insists that "you will have to search far and wide to find any suggestion of utopia or perfection in transhumanist writing" (More 14).
} 
that he/she/it embodies perfection, though his/her/its enumeration of posthuman delights may perhaps be interpreted as Bostrom's rhetorical device designed to instil the desire for transhumanist enhancement in his readers. More, by contrast, envisions the transhumanist change as a process of unending improvement and refrains from claiming that our posthuman future will be free from imperfections, risks or dangers. Nevertheless, his belief in perpetual perfectibility of human is equally utopian in its assumptions, even if he rejects the narrow understanding of utopia as the perfect state, which has actually become outdated in utopian studies: as Lyman Towers Sargent and other utopian scholars have pointed out on numerous occasions, "perfection has never been a characteristic of utopian fiction" (Sargent 6). More's extropian transhumanism relies on what Ruth Levitas has identified as the core of utopia understood as a method for imaginary reconstitution of society: "the desire for being otherwise, individually and collectively, subjectively and objectively. Its expressions explore and bring to debate the potential contents and contexts of human flourishing" (Levitas xi).

It is precisely this focus on human enhancement, as initially envisioned in secular humanism, that distinguishes transhumanism from posthumanism. Represented by such scholars as Cary Wolfe, Neil Badmington, N. Katherine Hayles and Donna Haraway, posthumanism questions the Renaissance and Enlightenment ideals of human perfectibility, rationality and agency, and seeks to go beyond the anthropocentric paradigm in the direction of the universe in which the hierarchical perception of humans, other living creatures, machines and even inanimate objects is abolished. As Wolfe points out, posthumanism paradoxically comes before and after humanism: on the one hand, it discloses the inevitable entanglement of the humanistic conception of the human in what it seeks to exclude, that is animalistic, machinic or material aspects of its nature; on the other it is embedded in the current (bio)technological transformation of the human:

\footnotetext{
posthumanism names a historical moment in which the decentering of the human by its imbrication in technical, medical, informatic, and economic networks is increasingly impossible to ignore, a historical development that points toward the necessity of new theoretical paradigms (but also thrusts them on us), a new mode of thought that comes after the cultural repressions and fantasies, the philosophical protocols and evasions, of humanism as a historically specific phenomenon. (xiv-xv)
}

This new understanding of the (post-)human ties in with blurring of differences between human and non-human. In her famous Manifesto for $\mathrm{Cy}$ borgs Donna Haraway argues that the technological progress of late twenti- 
eth century disclosed the discursive rather than essential nature of binary oppositions between natural and artificial, body and mind, animal and human, organism and machine. In posthumanism the posthuman thus becomes the figure for this heterogeneity: "In the posthuman, there are no essential differences or absolute demarcations between bodily existence and computer simulation, cybernetic mechanism and biological organism, robot teleology and human goals" (Hayles 3). Much as it embraces the technology-induced abolition of differences, posthumanism remains deeply sceptical of the transhumanist dream of perpetual progress, not least because it presupposes human perfectibility and agency. And yet, as Hauskeller observes, posthumanism can be construed in utopian terms:

... despite the widespread post-humanist opposition to trans-humanist technoutopianism, the desired and recommended dissolution of all confining boundaries is clearly itself a utopian idea, whether those boundaries are conceived as physical boundaries (as in transhumanism) or rather conceptual, that is, social and political boundaries (as in post-humanism). At the heart of post-humanism is clearly a liberationist ideal: the hoped-for redistribution of difference and identity is ultimately a redistribution of power. (23)

Significantly, just as posthumanism shares with transhumanism the utopian impulse, the latter, despite its focus on human enhancement, appears willing to grant the right to happiness to non-human modes of being: the Transhumanist Declaration "advocate[s] the well-being of all sentience, including humans, non-human animals, and any future artificial intellects, modified life forms, or other intelligences to which technological and scientific advance may give rise."

It is only speculative posthumanism proposed by Roden in Posthuman Life: Philosophy at the Edge of the Human as an alternative to transhumanism and critical/cultural posthumanism of Wolfe, Haraway and Hayles that appears to go beyond the utopian construction of the posthuman. As the adjective speculative indicates, rather than attributing a particular set of features to future human beings or envisioning abolition of anthropocentric hierarchies, speculative posthumanism characterises posthumans "in very general terms as hypothetical wide 'descendants' of current humans that are no longer human in consequence of some history of technological alteration," alteration being a neutral alternative to such value-laden terms as enhancement or augmentation, and claims that "such beings might be produced as part of a feasible future history" (105). Central to Roden's argument is a disconnection thesis - the assumption that these hypothetical beings will become posthuman when they cease to belong to what he calls Wide Human, socio-technological assemblage 
of humans and other entities, such as domesticated animals and technological devices, they depend on for their continued functioning. The concept of wide descent assumes in turn that the nature of the posthuman difference cannot be specified a priori: "Entities qualifying as posthuman might include our biological descendants or beings resulting from purely technical mediators (e.g. artificial intelligences, synthetic life-forms or uploaded minds" (Roden 108). This understanding of the posthuman flatly rejects the transhumanist assumption that posthumans will be in some sense better humans and "leaves the nature of posthumans open" (Roden 124).

The essays collected in this special issue of Anglica reflect all three conceptualisations of the notion of the posthuman and the various utopian underpinnings they entail. They range from the analyses of the representations of the transhumanist 'extended' or 'uploaded' versions of man, through the critical re-examination of humans in relation to others - nature or machines - to the envisioning of the future human/non-human relations and the possible forms of posthumanity. Likewise, the essays register and discuss a diversity of attitudes towards these possible or mostly only imaginary developments, that range from their satirical or jocular portrayals, through ideological embracement, to genuine fear and abhorrence provoked by the projected future scenarios. In addition, in keeping with the general cultural shift, the essays follow the change in the main narrative forms of texts, starting with the visions of utopia in prose, moving on to novels, to conclude with the recently much more prolific utopian/dystopian films and TV series. In so doing, the collection tries to present not only the panorama of various fictional incarnations of utopian (or sometimes dystopian) visions of (trans/ post)humanity but also to reflect upon their diverse and dynamic artistic shapes and very different attitudes they reflect and provoke.

Thus, the issue starts chronologically with discussions of older utopian visions, in Part One presenting four essays focused on early modern and nineteenth-century literary texts, which in various ways present sometimes quite outlandish projects of the future human. Expressing a variety of attitudes ranging from enthusiasm, through reflection, to sheer terror, the authors of these historical texts imagine the trans/posthuman as a creature that transgresses many boundaries held sacred at the time of their writing: the boundaries of race, sex, gender or species. The function of this crossing seems to be either rhetorical and aesthetic, elaborating and making more attractive the artistic shape of the texts, or ideological, drawing attention to aspects considered dangerous or commendable. Taken together, these texts 
envision the trans/posthuman as an imaginary quasi-monstrous creature rather than a project that has the slightest possibility of existence.

Part Two of the issue moves on to more contemporary texts: the essays included here discuss twentieth and twenty first-century novels and slightly more serious and less sensational visions of trans/posthumanity. The novels analysed in this part dramatise visions of a radically different world in which the conceptualisations of the human and his/her nature undergo a radical redefinition leading to the problematisation of the human/inhuman boundary and to the visions of alternative and much expanded possibilities of the relationship between the humans, natural environment and machines. This part demonstrates that the future brave new human may be imagined to exist along with other elements of the environment—plants, animals and/or machines-without hierarchical structures, exploitation and abuse. The analysed novels offer a very radical revision of the status and role of humans towards variously incarnated posthumanity, yet this revision is presented as a chance rather than a threat and as a difficult but necessary step towards the future: the Wide Human and the Posthuman.

Part Three of the issue focuses on the most recent narratives that depict various aspects of trans/posthumanity, and in keeping with the predominant narrative focus of the last decades it shifts towards cinematographic narratives, i.e. films and TV series. The essays collected in this section analyse popular and widely watched visual texts concentrating on the projections of the future new man and the possible problems this imaginary creature may encounter. These visions, on the one hand, optimistically offer a glimpse of hope for trans/posthumans by creating fictional spaces of peaceful and harmonious co-existence of various types of (in)human individuals and by indicating the possibility of their mutual respect and collaboration. On the other hand, they present scary scenarios of future nightmares which only slightly exaggerate and extrapolate the trends observable already in contemporary culture, and which indicate their possible grim consequences for (trans/ post)humans. The brave new human of the future, as imagined in the cinematographic texts discussed in this part, is thus equipped both with yet unknown freedom and possibilities, and at the same time a subject of various secret manipulations that seriously question his/her agency and independence. This section-and the whole issue-ends with the analysis of the film text which, paradoxically, presents a vision of neither a brave nor a pitiful new human but offers instead a nostalgic and quite conservative view of the (trans/post)humanity which longs for being human with all the limitations and imperfections this state entails. This narrative twist in a paradoxical conclusion draws attention to the ir- 
reducible element of any discussion of (trans/post)humanity, i.e. to the still 'human' part of the future man and returns us to the questions of the value of human existence despite or without trans/posthuman adjustments, expansions and alterations. In so doing, the issue traverses the territories of transhumanism, critical posthumanism and speculative posthumanism discussing various constructions of the concept of the human and their textual and cinematographic incarnations to return to the fundamental issue of humanity underlying all such discussions. Tracing the trajectory of the evolution of utopian visions of the brave new human, the essays record and analyse the shifts in narrative forms, the increasingly more serious treatment of the possible alterations of the human and the unceasingly ambivalent attitudes these possible or only imaginary changes provoke. It is our contention that the study of imaginary visions of (im)possible utopian and dystopian future scenarios, with their various rhetorical, ideological and aesthetic strategies, may contribute, in the truely utopian fashion, to the reflection on both the future and the present state of humanity.

\section{WORKS CITED}

Bostrom, Nick. "Letter from Utopia." 2010. Web.

Hauskeller, Michael. Mythologies of Transhumanism. Cham: Palgrave Macmillan, 2016. Print.

Hayles, N. Katherine. How We Became Posthuman: Virtual Bodies in Cybernetics, Literature, and Informatics. Chicago and London: The University of Chicago Press, 1999. Print.

Levitas, Ruth. Utopia as Method: The Imaginary Reconstitution of Society. Houndmills: Palgrave Macmillan, 2013.Print.

Mirandola, Giovanni Pico della. "Oration on the Dignity of Man.” The Renaissance Philosophy of Man. Ed. Ernst Cassirer, Paul Oskar Kristeller and John Herman Randall. Trans. Elizabeth Livermore Forbes. Chicago: The University of Chicago Press, 1948. 223-256. Print.

More, Max. "The Philosophy of Transhumanism." The Transhumanist Reader: Classical and Contemporary Essays on the Science, Technology, and Philosophy of the Human Future. Ed. Max More and Natasha Vita-More. Malden: Wiley-Blackwell, 2013. 3-17. Print.

Roden, David. Posthuman Life: Philosophy at the Edge of the Human. London and New York: Routledge, 2015. Print.

Sargent, Lyman Tower. “The Three Faces of Utopianism Revisited.” Utopian Studies 5.1 (1994): 1-37. Print.

Wolfe, Cary. What Is Posthumanism? Minneapolis and London: University of Minnesota Press, 2010. Print. 